\title{
Immunological characterization of human luteinizing hormone with special regard to a common genetic variant
}

\author{
C Nilsson, M Seppälä ${ }^{1}$ and $K$ Pettersson \\ Department of Biotechnology, University of Turku, Tykistökatu 6, FIN-20520 Turku, Finland \\ ${ }^{1}$ Wallac Oy, PO Box 10, FIN-20101 Turku, Finland \\ (Requests for offprints should be addressed to C Nilsson, Department of Biotechnology, University of Turku, Tykistökatu 6 A, 6 floor, FIN-20520 Turku, \\ Finland; Email: christel.nilsson@utu.fi)
}

\begin{abstract}
Immunoassays are widely used for measuring gonadotropins, including luteinizing hormone (LH), as these are both specific and sensitive. Because LH is microheterogeneous it has been claimed that the specificity of monoclonal antibodies used in two-site immunoassays can limit their clinical utility. Furthermore, we reported earlier a common genetic variant form of LH due to amino acid alterations in the LH $\beta$ gene that is poorly or not recognized by antibodies directed against epitopes present in the intact molecule. We here report the result of an LH epitope mapping using 30 different monoclonal antibodies. The antigenic area affected by the amino acid alterations is fairly large, as antibodies to the two intact domains are able to sandwich each other. Combinations of $\alpha-\beta$ or $\beta-\beta$
\end{abstract}

antibodies generally provide alternatives for unbiased detection of circulating $\mathrm{LH}$ and some have reasonably good discrimination of human chorionic gonadotropin. The $\beta-\beta$ combinations exhibit a peculiarity in urine determinations as they detect the urinary $\beta$-core fragment. Our aims were to study the altered immunoreactivity caused by the amino acid changes and to design two-site LH assays fully capable of recognizing the biologically active LH variant. We also conclude that the variability in recognizing the universally occurring $\mathrm{LH}$ variant is the most important factor contributing to the widely documented $\mathrm{LH}$ immunoassay discrepancies.

Journal of Endocrinology (2001) 168, 107-116

\section{Introduction}

The human (h) glycoprotein hormones luteinizing hormone (LH), chorionic gonadotropin (hCG) and folliclestimulating hormone (FSH) are required for normal reproduction. These hormones, along with thyroidstimulating hormone (TSH), are all $\alpha / \beta$-heterodimers with a common $\alpha$-subunit, whereas the $\beta$-subunit is unique and confers the hormone specificity. Both subunits are glycosylated at specific residues and the degree of glycosylation modulates the biological activity of the gonadotropins (Gharib et al. 1990). These hormones appear in blood and urine in a variety of forms ranging from heterodimeric intact molecules to small fragments (Birken et al. 1996).

Sensitive and specific assays of the gonadotropins are essential for assessment and treatment of fertility problems. LH and FSH are presently mostly determined by two-site immunoassays frequently using monoclonal antibodies (mab) recognizing different epitopes on the hormone molecule (Odell \& Griffin 1987, Pettersson \& Söderholm 1990). Variations in detectability of hormones by antibodies can depend on many factors affecting the epitope presentation such as posttranslational modifications, internal cleavages or fragmentations, interactions with other proteins or mutations. It is also possible that mabs may recognize the same epitope but with different affinities. Epitopes are generally thought to consist of linear and/or conformational segments of the polypeptide chain. As the glycoproteins are highly microheterogenous due to variations in the attached oligosaccharides, it is conceivable that these may influence the ligand detection of the mabs. The effect of carbohydrate heterogeneity on the immunoreactivity of antibodies against glycoprotein hormones remains highly controversial (Costagliola et al. 1994b, Berger et al. 1996). In addition it has been reported that glycosylation of the $\alpha$-subunit is essential for expression of the domains involved in hTSH immunoreactivity (Papandreou et al. 1991).

The high specificity of mabs may occasionally limit their clinical utility. For LH this was demonstrated by Pettersson et al. (1991) who reported that some commercial two-site immunoassays utilizing mabs recognizing the intact $\mathrm{LH}$ $\alpha / \beta$-heterodimer failed to detect a variant form of $\mathrm{LH}$. This common genetic variant $\mathrm{LH}$ form $(\mathrm{V}-\mathrm{LH})$ was later shown to be due to two point mutations in the LH $\beta$-subunit gene which both alter the amino acid sequence, 
Trp8 Arg and Ile15 Thr (Furui et al. 1994, Pettersson et al. 1994, Nilsson et al. 1998). Because of the amino acid change in codon 15, introducing a glycosylation consensus sequence, the $\mathrm{V}-\mathrm{LH}$ is suggested to have an extra carbohydrate chain at Asn13 similar to that exhibited by hCG (Talmadge et al. 1984) and by recombinantly produced V-LH (Suganuma et al. 1996).

The $\mathrm{LH}$ polymorphism due to these mutations is now known to be widely distributed in different populations, varying between zero and $52 \%$ in carrier frequency (Nilsson et al. 1997, 1998). The half-life of V-LH in circulation is shorter than that of wild type LH (WT-LH), but it has a higher in vitro bioactivity (Haavisto et al. 1995, Suganuma et al. 1996). The homozygotes for V-LH in the Finnish population are apparently healthy whereas Japanese findings have been connected to infertility (Suganuma et al. 1995, Takahashi et al. 1998). Some other clinical effects have also been reported. Fourteen-year-old boys heterozygotic for $\mathrm{V}-\mathrm{LH}$ have a slower progression of puberty as shown by testicular volume and height development (Raivio et al. 1996). V-LH also seemed to protect obese women from developing symptomatic polycystic ovarian syndrome (PCOS; Tapanainen et al. 1999), but this observation is not consistent in all studied populations (Rajkhowa et al. 1995).

The two point mutations causing the anomalous immunoreactivity obviously alter the epitope site which is recognized by intact $\mathrm{LH}$ specific mabs. Since mabs directed to the intact LH molecule often have low crossreactivities with hCG, these have been the preferred mabs used in commercial immunoassays highly specific for LH. In this study, we tested $32 \mathrm{LH}$ specific monoclonal antibodies in all possible two-site combinations in order to construct a relative epitope map. A major aim was to investigate which epitopes or epitope groups are affected by V-LH and to what extent. Using this information our intention was to identify two-site combinations with fully preserved recognition of $\mathrm{V}-\mathrm{LH}$ combined with a low cross-reactivity with hCG. Since selection of antibody combinations may profoundly affect recognition of $\mathrm{LH}$ forms in urine, we also wanted to test the selected mab combinations with urine samples.

\section{Materials and Methods}

Reagents

A total of 32 monoclonal antibodies against $\mathrm{LH}$ was included in this study. These were all purchased in purified form from various commercial sources (see Table 1), except INN-bLH-1, which was obtained in ascites fluid and purified by protein $\mathrm{G}$ chromatography. Based on the specifications provided by the manufacturers, two antibody pairs, M21241 and 090-10266, and M21301 and 090-11412, respectively, were most likely identical. Since this proposition was supported by the results of this study we refer to these pairs by the first code mentioned here.
The antibodies which recognize the $\alpha$-subunit are termed anti $\alpha$-subunit antibodies, the corresponding $\beta$ specific antibodies anti $\beta$-subunit antibodies and intact specific antibodies are referred to as intact LH specific antibodies.

All standards used, except LH $\beta$ (WHO International Reference Preparation (IRP) 75/551), were commercial DELFIA standards (Wallac Oy, Turku, Finland). Concentrations of the standards used were $324 \mathrm{mIU} / 1 \mathrm{TSH}, 256$ IU/1 FSH, $10000 \mathrm{IU} / 1 \mathrm{hCG}$ and $25 \mathrm{ng} / \mathrm{ml} \mathrm{LH \beta}$. Specific activities evaluated by commercial DELFIA immunoassay kits were: $6.4 \mathrm{IU} / \mathrm{mg}$ for TSH (2nd IRP, 80/558), 2100 $\mathrm{IU} / \mathrm{mg}$ for FSH (2nd IRP, 78/549), $9000 \mathrm{IU} / \mathrm{mg}$ for hCG (1st IRP 75/537) and 7300 IU/mg for LH (1st IRP $68 / 40)$.

\section{Samples}

Serum and urine samples were obtained from apparently healthy nonpregnant volunteers. Serum samples were collected from 5 men, 18 premenopausal women at different phases of the menstrual cycle, and from 4 postmenopausal women. Urine samples were collected randomly from 32 women. The V-LH sample was obtained from a premenopausal woman previously described by us (Pettersson et al. 1992). The blood samples were allowed to clot and the tubes were centrifuged before the sera were separated and stored at $-20{ }^{\circ} \mathrm{C}$ until analyzed. Urine samples were stored at $4{ }^{\circ} \mathrm{C}$.

\section{Coating of microtiter strip wells with monoclonal antibodies}

Polystyrene microtiter strips (Eflab, Helsinki, Finland) were coated with purified immunoglobulin $G(\operatorname{Ig} G)$ by physical adsorption as follows. To each well was added $1 \mu \mathrm{g}$ purified $\mathrm{IgG}$ in $100 \mu \mathrm{l} 0 \cdot 1 \mathrm{~mol} / 1 \mathrm{NaH}_{2} \mathrm{PO}_{4}$ and incubated at $35{ }^{\circ} \mathrm{C}$ for $16-20 \mathrm{~h}$. The wells were incubated, after a wash step, with $300 \mu \mathrm{l} 0 \cdot 1 \mathrm{~mol} / 1 \mathrm{NaH}_{2} \mathrm{PO}_{4}$ containing $6 \%$ sorbitol and $0 \cdot 1 \%$ bovine serum albumin for $1 \mathrm{~h}$ at room temperature. The blocking solution was then aspirated, the strips were covered with adhesive tape and stored in tight plastic bags with a humidifier at $4{ }^{\circ} \mathrm{C}$ for not more than 6 months.

\section{Labeling of antibodies}

The detection mabs were labeled as previously described (Lövgren et al. 1984). In short, a $5 \mathrm{mg} / \mathrm{ml}$ solution of antibody and a 120- to 1400-fold molar excess of europium-isothiocyanatophenyl-diethylene-triaminetetraacetic acid in $0.1 \mathrm{~mol} / \mathrm{l}$ borate buffer $(\mathrm{pH} 8.6)$ were incubated for $16-20 \mathrm{~h}$ at $4{ }^{\circ} \mathrm{C}$. The labeled antibody was then purified by gel filtration on a Sepharose $6 \mathrm{~B} /$ Sephadex G50 column (Pharmacia, Uppsala, Sweden) with $50 \mathrm{mmol} / 1$ Tris $-\mathrm{HCl}$, pH 7.75 containing $150 \mathrm{mmol} / 1$ $\mathrm{NaCl}$ and $7.75 \mathrm{mmol} / 1 \mathrm{NaN}_{3}$ as elution buffer. The $\mathrm{Eu} / \mathrm{IgG}$ ratio of the labeled antibodies varied from $2 \cdot 1$ to $7 \cdot 9$ and the protein concentrations according to $\mathrm{OD}_{280}$ 
varied between 10 and $95 \mu \mathrm{g} / \mathrm{ml}$. Two tracer antibodies, $8 \mathrm{~d} 10$ and 5301 from commercial DELFIA kits, had $\mathrm{Eu} / \mathrm{IgG}$ ratios of 9.9 and 14.2 respectively.

\section{Protocol for immunofluorimetric assays (IFMA)}

The following protocol was used for assaying serum and urine samples. First, $25 \mu \mathrm{l}$ of sample or standard solution were pipetted into each coated well followed by $100 \mu \mathrm{l}$ DELFIA assay buffer (Wallac Oy). Urine samples were pipetted after the assay buffer since this provided better assay precision. The plates were then incubated for $90 \mathrm{~min}$ at room temperature with continuous shaking, and washed once. Following addition of $50 \mathrm{ng}$ labeled tracer antibody in $150 \mu \mathrm{l}$ assay buffer, the wells were incubated for $30 \mathrm{~min}$ as above. The strips were then washed six times and $200 \mu \mathrm{l}$ enhancement solution were added (Wallac Oy). After shaking for $5 \mathrm{~min}$ and incubating for $15 \mathrm{~min}$, the fluorescence was measured in an Arcus fluorimeter (Wallac Oy).

\section{Screening of the monoclonal antibodies}

All the antibodies were tested in two-site assays with a 210 IU/1 LH standard and a blank by the following assay procedure. To coated, aspirated microtiter wells were pipetted $25 \mu \mathrm{l}$ of standard or blank solution, in duplicate, followed by $100 \mu \mathrm{l}$ assay buffer. The plates were then continuously shaken for $90 \mathrm{~min}$ at room temperature and washed once. After adding $50 \mathrm{ng}$ labeled tracer antibody in $150 \mu \mathrm{l}$ assay buffer to each well, the strips were incubated for $60 \mathrm{~min}$ and thereafter treated as described earlier.

\section{Adsorption tests}

The 30 mabs were tested for their ability to identify LH $\beta$, the other glycoprotein hormones and V-LH by adsorption tests. The microtiter wells coated with the different mabs were first washed three times and $100 \mu \mathrm{LH} \beta$, TSH, FSH, hCG standard solution or V-LH serum sample were pipetted into the wells. The samples were then allowed to adsorb to the capture antibody for $3 \mathrm{~h}$ at room temperature with continuous shaking. After removing the samples from the wells, the concentrations of the unbound hormones were assayed with the following assays: DELFIA LHSpec for LH $\beta$, DELFIA TSH for TSH, DELFIA FSH for FSH and DELFIA hCG for hCG (Wallac Oy). The V-LH serum sample was assayed with the reference method 5301/8d10 (Pettersson et al. 1992).

\section{Affinity determinations}

The affinity constants were determined for five Eu-labeled mabs as previously described (Pettersson \& Söderholm 1991). The procedure was essentially as described above for the IFMAs. In the first incubation $25 \mu \mathrm{lWT}$ - or V-LH serum sample were incubated with the capture antibody of the respective IFMA combination. After a wash step, the
LH bound to the capture antibody was titrated by increasing amounts of the labeled mab (12.5-400 ng/well). After subtracting the non-specific binding from the total binding, the data were used to calculate the affinities according to the method of Scatchard (1949).

\section{Statistics}

The results of the affinity and correlation studies were analyzed using Statview computer program (Abacus Concepts, Inc., Berkeley, CA, USA). The $P$ values of the affinity analysis were calculated by a paired $t$-test, $P$ values below $0 \cdot 05$ were considered statistically significant.

\section{Results}

\section{Immunological characterization of $\mathrm{LH}$}

The antibodies capabilities to bind to two different sites on the hormone molecule simultaneously were studied using a high LH standard (210 U/l) and a blank. For construction of the epitope map, we combined 30 different monoclonal antibodies in two-site assays in all possible ways. An epitope chart based on these results is shown in Fig. 1. Mabs capable of binding to the analyte simultaneously (= different epitopes) are shown as nonoverlapping ellipses. Antibodies that were unable to form a detectable sandwich signal (overlapping epitopes) are presented as partly overlapping ellipses. For many antibodies it was impossible to find any differences regarding their ability to sandwich the other antibodies. These antibodies are shown with their codes within the same ellipse. Using these 30 mabs we detected 20 different binding patterns (= ellipses in Fig. 1). These were grouped into six different epitope domains, two of which were directed against the $\alpha$-subunit, two against the $\beta$-subunit, and two epitope domains, fully separated from each other, only reactive with the intact $\mathrm{LH}$ dimer. From this epitope map it is evident that many principally different two-site combinations can be constructed; alpha-alpha, beta-beta, intact-intact, alpha-beta, alpha-intact and beta-intact.

\section{Cross-reactivities}

The cross-reactivities of the mabs with $\mathrm{LH} \beta$ and the other gonadotropins, hCG, FSH and TSH are presented in Table 1. These were determined after adsorbing the hormones to a capture antibody, and then measuring the levels of each gonadotropin, by a suitable assay, in the supernatants. Of the mabs which recognize epitope sites on the $\beta$-subunit, none reacted with FSH and one, 23c191, strongly cross-reacted with TSH. Five mabs, 094-10355, 5302, M94184, 5301 and 094-10711 crossreacted with hCG. The six anti $\alpha$-subunit antibodies reacted with all other glycoprotein hormones to varying degrees. The mabs which are specific for the intact $\mathrm{LH}$ 


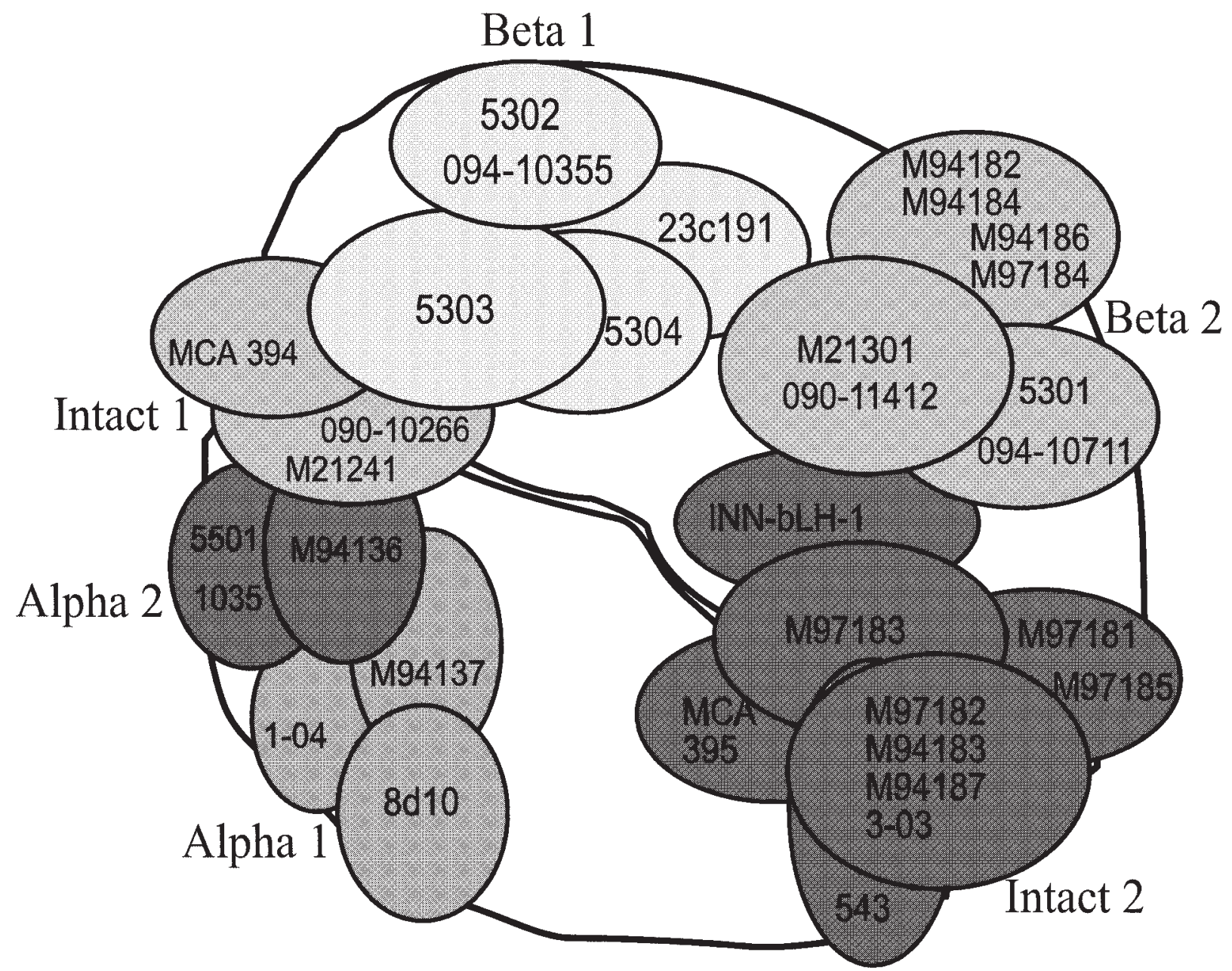

Figure 1 Epitope map of human luteinizing hormone. All 30 mabs were tested as both capture and detecting antibody in all possible combinations against each other in two-site assays. Six different epitope domains can be seen, two on each subunit and two on the intact molecule. Antibodies designated as being directed to the same epitope, that is, when they are written within an ellipse, will not bind to the hormone or its subunits simultaneously. Those antibodies which are directed to different epitope domains, presented in groups, were able to bind simultaneously to the LH molecule. Antibodies within an epitope domain and with overlapping epitopes, recognize the LH molecule poorly when they are used simultaneously. In other words, when antibodies from the same ellipse are used in a two-site assay no signal can be measured, whereas a good or even excellent signal level is obtained by combining non-overlapping antibodies from two different epitope domains.

heterodimer exhibited no binding of LH $\beta$, and showed no significant cross-reactivity to hCG, FSH or TSH in this test.

Figure 2 shows the percentage of $\mathrm{LH}$ adsorption from V-LH serum by 30 mabs. The inability of antibodies directed to the intact sites on the $\mathrm{LH}$ molecule to recognize V-LH is obvious. Five mabs, M21241, M97185, M97183, MCA 395 and INN-bLH-1, did not bind V-LH at all whereas other intact LH specific mabs, 543, M97181, M97182, M94183 and M94187, showed varying restricted reactivities with V-LH. Although mabs directed to the $\alpha$ - and $\beta$-domains as groups showed a higher reactivity with $\mathrm{V}-\mathrm{LH}$, the recognition by some mabs (e.g. M94137, 1035 and 5303) was clearly reduced.

\section{Performance of selected antibody combinations}

On the basis of the same results that were used for construction of the LH epitope map, 22 antibody combinations, preferably with subunit specific antibodies, were chosen for further studies (Table 2). A central criterion for selecting these combinations was the analytical performance, i.e. combining antibodies of good affinity against independent epitopes. Alpha-alpha combinations were excluded as they cross-reacted with all four glycoprotein hormones.

The cross-reactivities of the selected $22 \mathrm{mab}$ combinations to recognize TSH, FSH, hCG and LH $\beta$, shown in Table 2, were determined with a high standard 
Table 1 Description of the 30 commercial monoclonal antibodies used in this study. Information provided by the manufacturer is the affinity and the IgG class. The cross-reactivities, which were determined in this study, are given as + when over $90 \%$ of the glycoprotein in the sample was adsorbed, \pm when $90-30 \%$ was adsorbed, and as - when below $30 \%$ had been adsorbed by the antibody

\begin{tabular}{|c|c|c|c|c|c|c|c|c|c|}
\hline & & & & & Cro & eacti & & & \\
\hline & antibody & Manufacturer & manufacturer $(\mathrm{mol} / \mathrm{l})$ & class & $\overline{\mathrm{LH}}$ & $\mathrm{LH} \beta$ & hCG & $\mathrm{TSH}$ & $\mathrm{FSH}$ \\
\hline Epitope & & & & & & & & & \\
\hline Alpha 1 & $8 \mathrm{~d} 10$ & Wallac Oy & $2 \times 10^{11}$ & & + & - & + & + & + \\
\hline & $1-04^{*}$ & Scantibodies & $2 \times 10^{11}$ & $\lg \mathrm{G} 1$ & + & - & \pm & \pm & - \\
\hline & M94137 & Fitzgerald & $8 \times 10^{9}$ & $\lg G 1$ & + & - & - & - & - \\
\hline Alpha 2 & 5501 & Medix Biochemica & $2 \times 10^{9}$ & & + & - & \pm & \pm & - \\
\hline & 1035 & & & & + & - & \pm & \pm & \pm \\
\hline & M94136 & Fitzgerald & $4.0 \times 10^{10}$ & $\lg G$ & + & - & + & + & + \\
\hline Beta 1 & 23c191 & Wallac Oy & $2.4 \times 10^{10}$ & $\operatorname{lgG} 1$ & + & + & - & + & - \\
\hline & 094-10355 & OEM Concepts & $8 \times 10^{10}$ & $\lg G 1$ & + & + & \pm & - & - \\
\hline & 5302 & Medix Biochemica & $1 \times 10^{11}$ & & + & + & \pm & - & - \\
\hline & 5303 & Medix Biochemica & $3 \times 10^{11}$ & & + & + & - & - & - \\
\hline & 5304 & Medix Biochemica & & & + & + & - & - & - \\
\hline Beta 2 & M21301 & Fitzgerald & $3.7 \times 10^{10}$ & $\operatorname{lgG} 1$ & + & + & - & - & - \\
\hline & M94182 & Fitzgerald & $>2.0 \times 10^{9}$ & $\lg G 1$ & + & \pm & - & - & - \\
\hline & M94184 & Fitzgerald & $>5.0 \times 10^{10}$ & $\operatorname{lgG} 1$ & + & + & + & - & - \\
\hline & M94186 & Fitzgerald & $>4.0 \times 10^{10}$ & $\lg G$ & + & \pm & - & - & - \\
\hline & M97184 & Fitzgerald & $>4.1 \times 10^{10}$ & $\operatorname{lgG} 1 / \lg G 2 \mathrm{a}$ & + & \pm & - & - & - \\
\hline & 5301 & Medix Biochemica & $0.4 \times 10^{10}$ & $\lg \mathrm{G} 1$ & + & + & + & - & - \\
\hline & 094-10711 & OEM Concepts & $2 \times 10^{11}$ & $\lg \mathrm{g} 1$ & + & + & + & - & - \\
\hline Intact 1 & MCA $394^{*}$ & Serotec & & $\lg G 2 b$ & + & - & - & - & - \\
\hline & M21241 & Fitzgerald & $3 \cdot 2 \times 10^{10}$ & $\lg G 1$ & + & - & - & - & - \\
\hline Intact 2 & M97181 & Fitzgerald & $>1 \times 10^{9}$ & $\lg \mathrm{1} 1$ & + & - & - & - & - \\
\hline & M97185 & Fitzgerald & $>4.1 \times 10^{9}$ & $\operatorname{lgG} 1$ & + & - & - & - & - \\
\hline & M97182 & Fitzgerald & $>6.2 \times 10^{9}$ & $\lg \mathrm{A} 1$ & + & - & - & - & - \\
\hline & M94183 & Fitzgerald & $>2.0 \times 10^{9}$ & $\lg G 1$ & + & - & - & - & - \\
\hline & M94187 & Fitzgerald & $2 \times 10^{10}$ & $\lg G$ & + & - & - & - & - \\
\hline & $3-03^{*}$ & Scantibodies & $3 \times 10^{9}$ & $\operatorname{lgG} 1$ & + & - & - & - & - \\
\hline & M97183 & Fitzgerald & $>1.0 \times 10^{9}$ & $\lg G 1$ & + & - & - & - & - \\
\hline & MCA $395^{*}$ & Serotec & & $\operatorname{lgG} 1$ & + & - & - & - & - \\
\hline & 543 & Argene Biosoft & $7 \cdot 7 \times 10^{6}$ & & + & - & - & - & - \\
\hline & INN-bLH-1* & Serotec & & $\lg G$ & + & - & - & - & - \\
\hline
\end{tabular}

Scantibodies, Santee, CA, USA; Fitzgerald, Concord, MA, USA; Medix, Kauniainen, Finland; OEM Concepts, Toms River, NJ, USA; Serotec, Oxford, Oxon, UK; Argene Biosoft, Varilhes, France.

*Not currently available.

concentration of the hormone preparation. It is worth noting that the combinations with the intact LH specific mab, M94187, showed very low cross-reactivities with hCG. The three combinations with the anti $\beta$-subunit mab 5303, which is close to the intact 1 domain, had the lowest cross-reactivities with hCG as a group. The TSH standard contained trace amounts of $\mathrm{LH}$ which is obvious when the cross-reactivities for 23c191/5301 using two different preparations are compared (Pettersson \& Söderholm 1990). The LH $\beta$ preparation was apparently also contaminated with some intact $\mathrm{LH}$, explaining the cross-reactivity with the intact/alpha combination. In this study, good combinations for detecting V-LH with low hCG cross-reactivity were 23c191/5301, 5304/5301 and $5304 / 8 \mathrm{~d} 10$.

\section{Correlations}

Individual serum samples from premenopausal women at different phases of the menstrual cycle, postmenopausal women and male samples, $n=27$, as well as 32 female urine samples were measured by the $22 \mathrm{mab}$ combinations (data not shown). Of these combinations, the results from seven assays were chosen for correlation analyses, of which 5301/8d10 was used as reference assay (shown in Fig. 3). The overall correlations for the serum samples were all very good, $\mathrm{R}>0.987$, independent of the type of antisubunit combination. Urine and serum samples correlations were very similar when the $\beta / \alpha$ combinations were correlated with the $\beta / \alpha$ reference combination. The two $\beta / \beta$ combinations, $23 c 191 / 5301$ and M94184/23c191, detected variably, but predominantly, twofold (ratio 2.09) higher immunoreactivities in the urine samples compared with the $\beta / \alpha$ assays. For the two $\beta / \beta$ combinations the urine sample correlations were 0.470 and 0.860 , and for the other combinations they were $>0.994$. The two $\beta / \beta$ combinations correlated excellently to each other regarding the serum samples, $\mathrm{R}=0.9997$, and moderately for the urine samples, $\mathrm{R}=0 \cdot 830$. The average measured $\mathrm{LH}$ 


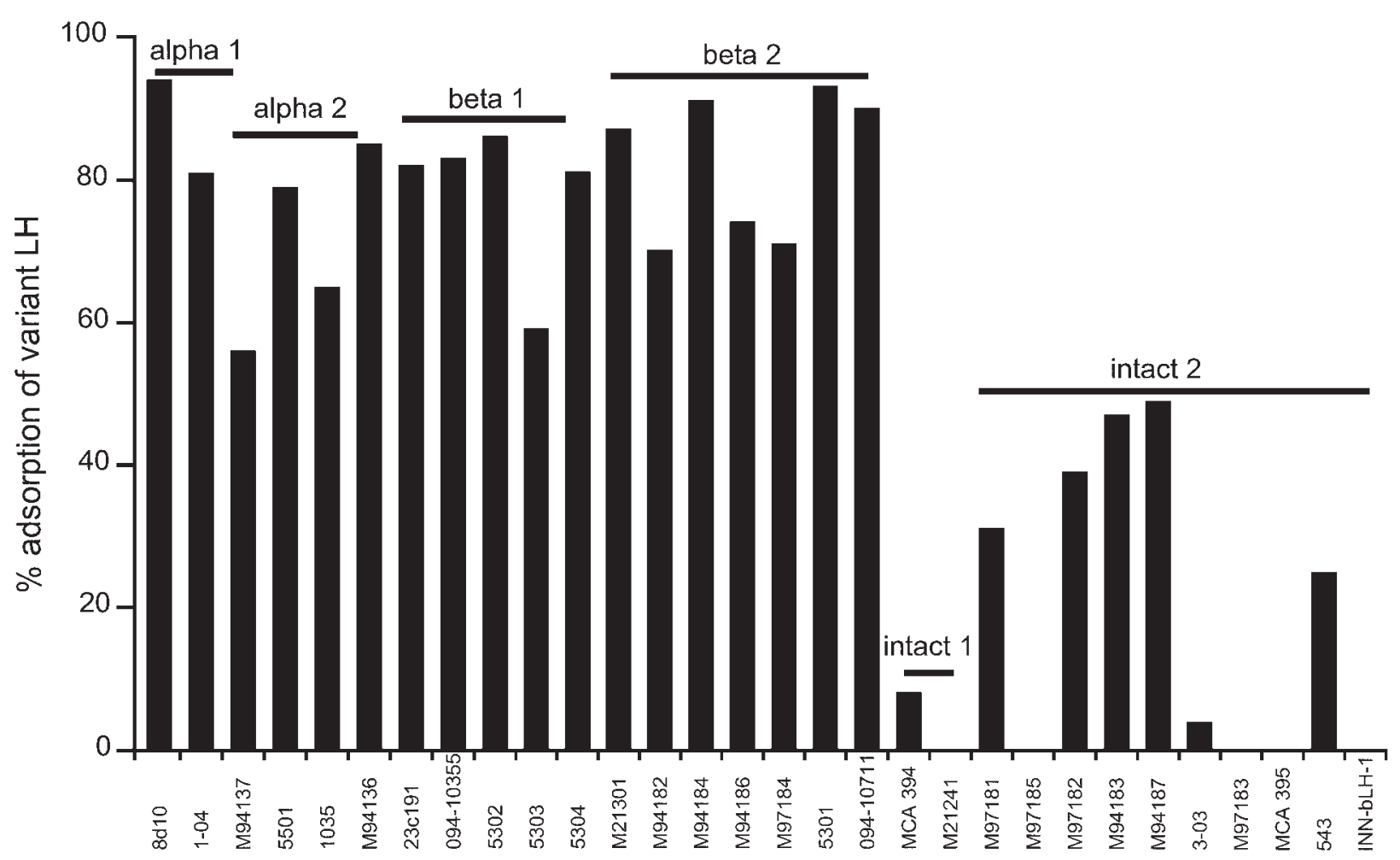

Figure 2 Adsorption of variant LH from a serum sample by 30 mabs. Antibodies directed to the intact sites on the LH molecule did not recognize V-LH or recognized it poorly compared with subunit specific mabs. Mabs M21241, M97185, M97183, MCA 395 and INN-bLH-1 did not bind V-LH at all whereas the other mabs at the intact sites reacted poorly with V-LH.

concentration ratio of the two $\beta / \beta$ combinations was 1.92 (data not shown). The regression line between them was $\mathrm{y}_{\mathrm{M} 94184 / 23 \mathrm{c} 191}=-2 \cdot 81+0 \cdot 61 \star_{\mathrm{X}_{23 \mathrm{c} 191 / 5301} \text {, showing a }}$ marked difference in slope.

\section{Affinities of five mabs to WT- and V-LH}

We determined the affinity constants of five labeled mabs $(1 \alpha, 2 \beta$ and 2 intact) using serum samples from three individuals of WT-LH and three individuals homozygous for $\mathrm{V}-\mathrm{LH}$. The average affinities \pm S.D. of the five mabs for the two groups of serum LH are presented in Table 3. No significant differences in affinity constants were seen for the labeled anti $\alpha$-subunit or anti $\beta$-subunit mabs. The affinity of the intact LH specific antibody M94187 was, however, significantly lower for $\mathrm{V}-\mathrm{LH}$ compared with WT-LH $(0 \cdot 18 \pm 0 \cdot 04$ E9 vs $0 \cdot 6 \pm 0 \cdot 13$ E9; $P<0 \cdot 028)$. With the intact LH specific mab M21241, the affinity constant for WT-LH was $1 \cdot 88 \pm 0 \cdot 21$ E9 but no binding was detected for the V-LH samples.

\section{Discussion}

The pronounced heterogeneity of the glycoprotein hormones, which predominantly is a result of variations in the carbohydrate moieties, is well documented (Burgon et al. 1996, Phillips et al. 1997). Whether or not this heterogeneity is reflected in the way antibodies recognize glycoprotein hormones has been highly controversial (Costagliola et al. 1994b, Mitchell et al. 1995, Berger et al. 1996). The explanation for the anomalous immunoreactivity of the LH variant described by us in 1991 (Pettersson \& Söderholm 1991) was, however, shown to be two amino acid alterations in the LH $\beta$ gene (Furui et al. 1994, Pettersson et al. 1994, Nilsson et al. 1998). The main aim of this study was to investigate a large selection of commercially available anti LH mabs for their reactivity with WT- and V-LH. This is important both for estimating the extent of the antigenically modified area in V-LH as well as for identifying antibody combinations that can provide equal recognition of these two biologically active forms (WT- and V-LH) while still minimizing the co-identification of hCG. Further, we intended to evaluate and compare the performance of the selected pairs of antibodies using serum and urine samples. Our study shows that a large area of the V-LH epitope determining region is altered, as all intact $\mathrm{LH}$ specific antibodies exhibited restricted reactivity for this LH form. We also identified three immunoassays fulfilling our criteria, and excellent correlations were obtained with $\alpha-\beta$ and $\beta-\beta$ 
Table 2 Cross-reactivites of gonadotropins with 22 different two-site $\mathrm{LH}$ assays performed in two steps. The standard concentrations of the gonadotropins used were: $324 \mathrm{mIU} / \mathrm{I} \mathrm{TSH}, 256 \mathrm{IU} / \mathrm{I} \mathrm{FSH,} 10000 \mathrm{IU} / \mathrm{l} \mathrm{hCG}$ and $25 \mathrm{ng} / \mathrm{ml} \mathrm{LH} \beta$

\begin{tabular}{|c|c|c|c|c|c|c|}
\hline & \multirow{2}{*}{$\begin{array}{l}\text { Detector } \\
\text { antibody }\end{array}$} & \multirow[b]{2}{*}{$\boldsymbol{\alpha} / \boldsymbol{\beta} / \mathbf{I}$} & \multicolumn{4}{|c|}{ Cross-reaction (w/w in \%) } \\
\hline & & & TSH & FSH & hCG & $\mathrm{LH} \beta$ \\
\hline \multicolumn{7}{|l|}{$\begin{array}{l}\text { Capture } \\
\text { antibody }\end{array}$} \\
\hline M21301 & 5303 & $\beta / \beta$ & $1 \cdot 73$ & $0 \cdot 01$ & 0.00 & $61 \cdot 74$ \\
\hline \multirow[t]{6}{*}{ M94187 } & M21301 & $\mathrm{I} / \beta$ & $1 \cdot 09$ & $0 \cdot 01$ & $0 \cdot 05$ & $7 \cdot 46$ \\
\hline & M94184 & $1 / \beta$ & $1 \cdot 16$ & $0 \cdot 02$ & $2 \cdot 35$ & $7 \cdot 06$ \\
\hline & $23 c 191$ & $\mathrm{I} / \beta$ & $1 \cdot 22$ & $0 \cdot 00$ & $0 \cdot 06$ & $7 \cdot 85$ \\
\hline & 5302 & $\mathrm{I} / \beta$ & $1 \cdot 22$ & $0 \cdot 01$ & $1 \cdot 09$ & $7 \cdot 53$ \\
\hline & 5303 & $\mathrm{I} / \beta$ & $1 \cdot 21$ & $0 \cdot 00$ & $0 \cdot 01$ & $6 \cdot 79$ \\
\hline & $8 d 10$ & $\mathrm{I} / \alpha$ & $1 \cdot 17$ & $0 \cdot 00$ & $2 \cdot 45$ & $6 \cdot 51$ \\
\hline \multirow[t]{3}{*}{ M94184 } & $23 c 191$ & $\beta / \beta$ & $1 \cdot 38$ & 0.00 & $15 \cdot 85$ & $72 \cdot 54$ \\
\hline & 5303 & $\beta / \beta$ & $1 \cdot 65$ & $0 \cdot 01$ & $0 \cdot 80$ & 61.67 \\
\hline & $8 d 10$ & $\beta / \alpha$ & $1 \cdot 80$ & $0 \cdot 01$ & $45 \cdot 38$ & $7 \cdot 99$ \\
\hline $23 c 191$ & 5301 & $\beta / \beta$ & $1 \cdot 76$ & $0 \cdot 00$ & $1 \cdot 85$ & $71 \cdot 15$ \\
\hline $23 \mathrm{c} 191^{*}$ & 5301 & $\beta / \beta$ & 0.002 & 0.003 & $1 \cdot 0$ & 66 \\
\hline \multirow[t]{4}{*}{5301} & $23 c 191$ & $\beta / \beta$ & $1 \cdot 59$ & $0 \cdot 01$ & $14 \cdot 35$ & $65 \cdot 21$ \\
\hline & M94136 & $\beta / \alpha$ & $1 \cdot 46$ & $0 \cdot 01$ & $44 \cdot 02$ & $8 \cdot 00$ \\
\hline & $8 \mathrm{~d} 10$ & $\beta / \alpha$ & $1 \cdot 37$ & 0.00 & $44 \cdot 17$ & $7 \cdot 95$ \\
\hline & 5501 & $\beta / \alpha$ & $1 \cdot 64$ & $0 \cdot 00$ & $52 \cdot 47$ & $7 \cdot 25$ \\
\hline \multirow[t]{2}{*}{5302} & 5301 & $\beta / \beta$ & $1 \cdot 54$ & $0 \cdot 00$ & $25 \cdot 96$ & 63.55 \\
\hline & $8 \mathrm{~d} 10$ & $\beta / \alpha$ & $1 \cdot 24$ & $0 \cdot 00$ & $35 \cdot 59$ & $7 \cdot 72$ \\
\hline \multirow[t]{3}{*}{5303} & M94186 & $\beta / \beta$ & $1 \cdot 76$ & 0.00 & $0 \cdot 03$ & $71 \cdot 27$ \\
\hline & 5301 & $\beta / \beta$ & $1 \cdot 61$ & 0.00 & 0.06 & $64 \cdot 11$ \\
\hline & $8 \mathrm{~d} 10$ & $\beta / \alpha$ & $1 \cdot 32$ & $0 \cdot 86$ & 0.02 & 8.06 \\
\hline \multirow[t]{2}{*}{5304} & 5301 & $\beta / \beta$ & $1 \cdot 60$ & $0 \cdot 01$ & $0 \cdot 34$ & $64 \cdot 83$ \\
\hline & $8 \mathrm{~d} 10$ & $\beta / \alpha$ & $1 \cdot 20$ & $0 \cdot 04$ & $0 \cdot 30$ & $7 \cdot 90$ \\
\hline
\end{tabular}

*In this experiment reported earlier (Pettersson \& Söderholm 1990) an ultrapure preparation of TSH and FSH was used.

combinations using serum samples. In applying these assays to urine samples, large differences were obtained between $\alpha-\beta$ and $\beta-\beta$ combinations as well as between differently configured $\beta-\beta$ assays.

For the immunological characterization of $\mathrm{LH}$ we combined 30 different monoclonal antibodies in all possible ways in order to investigate which antibodies were able to bind simultaneously to the LH molecule. Immunological mapping has been used for developing measuring techniques and has also helped to understand topographical relationships among major surface features (AlonsoWhipple et al. 1988). In our epitope map six different epitope domains were distinguished, two on the intact hormone molecule, two on the $\beta$-subunit and two overlapping sites on the $\alpha$-subunit (Fig. 1). Earlier, Krichevsky et al. (1994) located seven antibody-binding regions on $\mathrm{LH}$ using an extensive library of mabs developed in their laboratory, and Costagliola et al. $(1994 a, b)$ distinguished 21 clusters of reactivity on the surface of the LH heterodimer. It should be acknowledged, however, that mab epitopes, as evident also from this study, rarely form totally discrete units or epitope domains but rather are arranged into a continuum of binding patterns.

In the present study we have shown that antibodies which recognize the two independent intact $\mathrm{LH}$ dimer epitope domains, as well as some $\alpha$ - and $\beta$-antibodies in their close vicinity (e.g. M94137, 1035 and 5303), show variably restricted reactivity to $\mathrm{V}-\mathrm{LH}$. The restricted reactivity ranges from complete inability to recognize the variant to a decrease in the affinity constant relative to WT-LH. This indicates that a fairly large topographic area of the LH $\beta$ molecule is affected by the amino acid changes in Trp8 Arg and Ile15 Thr. The altered immunoreactivity is probably due to conformational changes in the protein because both mutations render the $\mathrm{NH}_{2}$-terminus more hydrophilic. Another possibility is that the putative additional carbohydrate residue at Asn13 could block the epitopes on the intact LH molecule.

In order to achieve a low cross-reactivity with hCG and good recognition of $\mathrm{V}-\mathrm{LH}$, several aspects have to be considered in selecting mabs for a two-site $\mathrm{LH}$ immunoassay. Combinations using an anti $\alpha$-subunit specific antibody as capture mab are excluded, as these would be influenced by all glycoprotein hormones. In a combination with an anti $\beta$-subunit specific capture mab and an anti $\alpha$-subunit specific detecting mab, the specificity of the assay relies totally on the anti $\beta$-subunit specific mab. One has to remember that some anti $\beta$-subunit specific mabs are so close to the intact LH epitope domains that they do not recognize V-LH properly. An example of this in our study is the anti $\beta$-subunit specific mab 5303, which has a very low cross-reactivity 

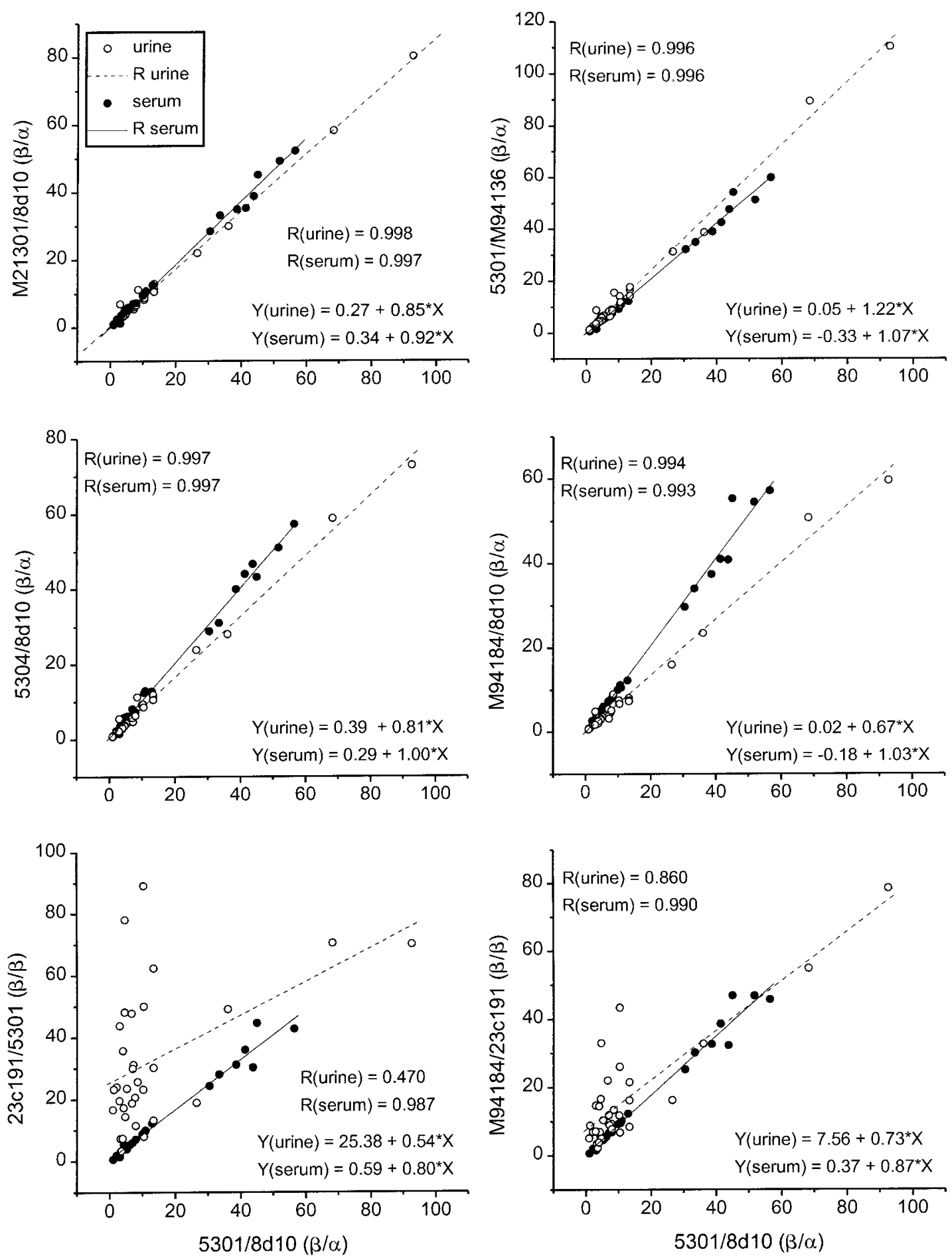

Figure 3 Comparison of six different immunoassays utilizing subunit specific antibodies with the reference $\beta / \alpha$ method $5301 / 8 \mathrm{~d} 10$. The results for the serum samples correlate well with $\mathrm{R}$ values over 0.92. Urine samples give higher concentrations with the $\beta / \beta$ combinations, due to recognition of fragmented LH $\beta$ molecules causing the lower correlations. The regression coefficients can be seen from the equations for each regression line. The slopes for the serum sample lines were relatively similar for all combinations and varied between 0.80 and $1 \cdot 07$. The higher $\mathrm{LH}$ values obtained with the $\beta / \beta$ combinations for the urine samples are reflected by the decreased slopes, $0 \cdot 54$ and $0 \cdot 73$ for $23 c 191 / 5301$ and M94184/23c191 respectively. 
Table 3 Average affinity constants of three serum samples for five monoclonal antibodies. Capture mabs were 090-11412 in combination with 8d10, M94187 and M21241, 5301 with 23c191, and 23c191 with 5301. The value was not obtained for the intact antibody M21241 when samples from individuals homozygous for the point mutations in the LH $\beta$ gene were analyzed. Generally, intact (int) antibodies reacted poorly with V-LH. The affinities are expressed as E9

\begin{tabular}{|c|c|c|c|c|c|}
\hline & 8d10 $(\alpha)$ & M94187 (int) & M21241 (int) & $23 c 191(\beta)$ & $5301(\beta)$ \\
\hline WT-LH & $33 \cdot 8 \pm 0 \cdot 21$ & $0 \cdot 60 \pm 0 \cdot 13$ & $1 \cdot 88 \pm 0 \cdot 21$ & $4 \cdot 78 \pm 0 \cdot 12$ & $4 \cdot 11 \pm 1 \cdot 19$ \\
\hline V-LH & $35 \cdot 1 \pm 6 \cdot 65$ & $0 \cdot 18 \pm 0 \cdot 04^{\star}$ & & $9 \cdot 61 \pm 0 \cdot 78$ & $3 \cdot 23 \pm 0.53$ \\
\hline
\end{tabular}

${ }^{*} P=0 \cdot 028$ compared with WT-LH samples.

with hCG but recognizes $\mathrm{V}-\mathrm{LH}$ poorly. Combinations employing anti $\beta$-subunit specific mabs for capture and detection not only measure the biologically active dimer, as $\beta / \alpha$ combinations do, but also recognize free $\beta$ subunits and fragmented forms to varying degrees. Unfortunately, they often have high cross-reactivities with hCG although reasonably specific mabs for $\mathrm{LH} \beta$ are available, such as 23c191, M21301 and M94186 in this study. Intact LH specific mabs should be excluded, as these do not recognize V-LH and WT-LH similarly.

Apart from having a closely similar $\alpha$-subunit, the amino acid sequence homology of hCG $\beta$ and $\mathrm{LH} \beta$ is as high as 80 percent (Talmadge et al. 1984) and thus the construction of LH assay designs not recognizing hCG has been difficult. The amino terminal amino acid differences of the LH $\beta$ subunit and the lack of Asn13 carbohydrate moiety, and its association with the $\alpha$-subunit evidently constitute a strong antigenic determinant that has enabled the development of $\mathrm{LH}$ antibodies highly discriminative with regard to hCG. This specificity advantage explains the popularity of antibodies against the intact heterodimer in numerous commercial tests (Costagliola et al. 1994b). Unfortunately, such assays were too specific in the sense that V-LH, due to its similarity to hCG, was equally poorly detected.

Costagliola et al. $(1994 a, b)$ reported a study which was designed to understand the causes of discrepancy among LH immunoassay methods. They suggested that the immunoreactivity of $\mathrm{LH}$ depends more on the purification than upon the origin of the preparation (pituitary or urinary). Comparison of 11 commercial mab-based kits indicated that discrepancy among LH assay kits was related to variation in kit calibration and in epitope specificity of the mabs used. However, they also reported five kits, all using intact LH specific detector antibodies, which misrecognized circulating LH in some subjects.

Regarding measurement of $\mathrm{LH}$ concentrations in urine, it has to be considered that urine to a large degree also contains free subunits, as well as fragmented forms of LH $\beta$ (Kovalevskaya et al. 1995, Birken et al. 1996). The performance of intact LH specific mabs is similar, with dimeric LH found in both urine and serum, and they show a restricted reactivity towards $\mathrm{V}-\mathrm{LH}$. The two $\beta-\beta$ mab combinations reported here can detect several-fold higher urine $\mathrm{LH}$ concentrations relative to the reference mab combination detecting only intact LH, and with fairly poor correlations. The regression line between them showed a moderate correlation $(\mathrm{R}=0.83)$ and a substantial difference in slope $(0 \cdot 61)$. This amply illustrates the variability of different antibody combinations in recognizing the various fragments of the LH $\beta$-subunit present in urine.

From the comparison of numerous two-site combinations involving the different antigenic domains and their performance with patient specimens, we conclude that the single most important factor in explaining LH immunoassay discrepancies is the lack of ability to detect variant $\mathrm{LH}$. Combinations with $\beta-\beta$ and $\alpha-\beta$ specific mabs generally correlate excellently to each other although some anti $\beta$-subunit specific mabs in close vicinity to the intact domain show similar problems as assays involving intact LH specific mabs. This conclusion should not, however, be interpreted so as to exclude the possibility that other sources of LH heterogeneity can influence immunoassay behavior. It should also be kept in mind that the excess reagent situations usually applying to sandwich assays make possible affinity differences between isoforms less influential.

It is of interest to compare the findings of the present study with the hCG/LH receptor interaction model suggested by Cosowsky et al. (1995). According to this hypothesis the groove formed by the $\beta 1-, \beta 3$ - and $\alpha$ 2 -loops mediates the ligand binding to a segment of the receptor. The putative additional carbohydrate moiety at Asn13 may also, according to the same model, contribute to hormone efficacy by providing 'extra bulk', enhancing the interaction with the extra-cellular domains of the receptor. The large immunologically affected area in the $\alpha-\beta$ interface of $\mathrm{V}-\mathrm{LH}$, the likelihood of an additional sugar moiety, and the reported findings of potentiated receptor interaction of $\mathrm{V}-\mathrm{LH}$ (Haavisto et al. 1995, Suganuma et al. 1996) could conceivably fit the model proposed by Cosowsky et al., although this remains speculative at the present stage.

Despite numerous investigations (Rajkhowa et al. 1995, Suganuma et al. 1995, Raivio et al. 1996, Tapanainen et al. 1999), no major pathologies have been clearly associated with the presence of V-LH in hetero- or homozygous form. This is not surprising in view of the high prevalence of this polymorphism found in various populations around the world. Being fully biologically active, the variant LH 
should, therefore, be determined in routine LH assays with equimolar potency as WT-LH.

\section{References}

Alonso-Whipple C, Couet ML, Doss R, Koziarz J, Ogunro EA \& Crowley WF 1988 Epitope mapping of human luteinizing hormone using monoclonal antibodies. Endocrinology 123 1854-1860.

Berger P, Bidart JM, Delves PS, Dirnhofer S, Hoermann R, Isaacs N, Jackson A, Klonisch T, Lapthorn A, Lund T, Mann K, Roitt I, Schwarz S \& Wick G 1996 Immunochemical mapping of gonadotropins. Molecular and Cellular Endocrinology 125 33-43.

Birken S, Kovalevskaya G \& O'Connor J 1996 Metabolism of hCG and hLH to multiple urinary forms. Molecular and Cellular Endocrinology 125 121-131.

Burgon PG, Stanton PG \& Robertson DM 1996 In vivo bioactivities and clearance patterns of highly purified human luteinizing hormone isoforms. Endocrinology 137 4827-4836.

Cosowsky L, Rao SNV, Macdonald GJ, Papkoff H, Campbell RK \& Moyle WR 1995 The groove between the $\alpha$ - and $\beta$-subunits of hormones with lutropin (LH) activity appears to contact the $\mathrm{LH}$ receptor, and its conformation is changed during hormone binding. Journal of Biological Chemistry 270 20011-20019.

Costagliola S, Niccoli P, Florentino M \& Carayon P 1994a European collaborative study of luteinizing hormone assay. 1. Epitope specificity of luteinizing hormone monoclonal antibodies and surface mapping of pituitary and urinary luteinizing hormone. Journal of Endocrinological Investigation 17 397-406.

Costagliola S, Niccoli P, Florentino M \& Carayon P $1994 b$ European collaborative study on luteinizing hormone assay. 2. Discrepancy among assay kits is related to variation both in standard curve calibration and epitope specificity of kit monoclonal antibodies. Journal of Endocrinological Investigation 17 407-416.

Furui K, Suganuma N, Tsukahara S-I, Asada Y, Kikkawa F, Tanaka M, Ozawa T \& Tomoda Y 1994 Identification of two point mutations in the gene coding luteinizing hormone (LH) $\beta$-subunit, associated with immunologically anomalous LH variants. Journal of Clinical Endocrinology and Metabolism 78 107-113.

Gharib SD, Wierman ME, Shupnik MA \& Chin WW 1990 Molecular biology of the pituitary gonadotropins. Endocrine Reviews 11 177-199.

Haavisto AM, Pettersson K, Bergendahl M, Virkamäki A \& Huhtaniemi I 1995 Occurrence and biological properties of a common genetic variant of luteinizing hormone. Journal of Clinical Endocrinology and Metabolism 80 1257-1263.

Kovalevskaya G, Birken S, O'Connor J, Schlatterer J, Maydelman Y \& Canfield R 1995 hLH beta core fragment immunoreactivity in the urine of ovulating women: a sensitive and specific immunometric assay for its detection. Endocrine 3 881-887.

Krichevsky A, Birken S, O'Connor JF, Bikel K, Schlatterer JP \& Canfield RE 1994 The development of a panel of monoclonal antibodies to human luteinizing hormone and its application to immunological mapping and two-site assays. Endocrine 2 511-520.

Lövgren T, Hemmilä I, Pettersson K, Eskola JU \& Bertoft E 1984 Determination of hormones by time-resolved fluoroimmunoassay. Talanta 31 909-916.

Mitchell R, Hollis S, Crowley V, McLoughlin J, Peers N \& Robertson WR 1995 Immunometric assays of luteinizing hormone (LH): differences in recognition of plasma LH by anti-intact and $\beta$-subunit-specific antibodies in various physiological and pathophysiological situations. Clinical Chemistry 41 1139-1145.

Nilsson C, Pettersson K, Millar RP, Coerver KA, Matzuk MM \& Huhtaniemi IT 1997 Worldwide frequency of a common genetic variant of luteinizing hormone: an international collaborative research. Fertility and Sterility 67 998-1004.

Nilsson C, Jiang M, Pettersson K, Iitiä A, Mä kelä M, Simonsen H, Easteal S, Herrera RJ \& Huhtaniemi I 1998 Determination of a common genetic variant of luteinizing hormone using DNA hybridization and immunoassays. Clinical Endocrinology 49 369-376.

Odell WD \& Griffin J 1987 Two-monoclonal-antibody 'sandwich-'type assay of human lutropin, with no cross reaction with choriogonadotropin. Clinical Chemistry 33 1603-1607.

Papandreou MJ, Sergi I, Medri G, Labbe-Jullie C, Braun JM, Canonne C \& Ronin C 1991 Differential effect of glycosylation on the expression of antigenic and bioactive domains in human thyrotropin. Molecular and Cellular Endocrinology 78 137-150.

Pettersson K \& Söderholm JR 1990 Ultrasensitive two-site immunometric assay of human lutropin by time-resolved fluorimetry. Clinical Chemistry 36 1928-1933.

Pettersson K \& Söderholm JR 1991 Individual differences in lutropin immunoreactivity revealed by monoclonal antibodies. Clinical Chemistry 37 333-340.

Pettersson K, Ding YQ \& Huhtaniemi I 1991 Monoclonal antibody-based discrepancies between two-site immunometric tests for lutropin. Clinical Chemistry 37 1745-1748.

Pettersson K, Ding YQ \& Huhtaniemi I 1992 An immunologically anomalous luteinizing hormone variant in a healthy woman. Journal of Clinical Endocrinology and Metabolism 74 164-171.

Pettersson K, Mäkelä MM, Dahlén P, Lamminen T, Huoponen K \& Huhtaniemi I 1994 Gene polymorphism found in the LH beta gene of an immunologically anomalous variant of human luteinizing hormone. European Journal of Endocrinology 130 (Suppl. 2) 65.

Phillips DJ, Albertsson-Wikland K, Eriksson K \& Wide L 1997 Changes in the isoforms of luteinizing hormone and folliclestimulating hormone during puberty in normal children. Journal of Clinical Endocrinology and Metabolism 82 3103-3106.

Raivio T, Huhtaniemi I, Anttila R, Siimes MA, Hagenäs L, Nilsson C, Pettersson K \& Dunkel L 1996 The role of luteinizing hormone- $\beta$ gene polymorphism in the onset and progression of puberty in healthy boys. Journal of Clinical Endocrinology and Metabolism 81 3278-3282.

Rajkhowa M, Talbot JA, Jones PW, Pettersson K, Haavisto AM, Huhtaniemi I \& Clayton RN 1995 Prevalence of an immunological LH $\beta$-subunit variant in a UK population of healthy women and women with polycystic ovary syndrome. Clinical Endocrinology 43 297-303.

Scatchard G 1949 The attractions of proteins for small molecules and ions. Annals of the New York Academy of Sciences 51 660-672.

Suganuma N, Furui K, Furuhashi M, Asada Y, Kikkawa F \& Tomoda Y 1995 Screening of the mutations in luteinizing hormone $\beta$-subunit in patients with menstrual disorders. Fertility and Sterility 63 989-995.

Suganuma N, Furui K, Kikkawa F, Tomoda Y \& Furuhashi M 1996 Effects of mutations $(\operatorname{Trp} 8 \rightarrow$ Arg and Ile $15 \rightarrow$ Thr) in human luteinizing hormone ( $\mathrm{LH}) \beta$-subunit on $\mathrm{LH}$ bioactivity in vitro and in vivo. Endocrinology 137 831-838.

Takahashi K, Kurioka H, Ozaki T, Kanasaki H, Kohsaka M, Miyazaki K \& Karino K 1998 Increased prevalence of luteinizing hormone beta-subunit variant in Japanese infertility patients. Human Reproduction 13 3338-3344.

Talmadge K, Vamvakopoulos NC \& Fiddes JC 1984 Evolution of the genes for the $\beta$ subunits of human chorionic gonadotropin and luteinizing hormone. Nature 307 37-40.

Tapanainen JS, Koivunen R, Fauser BC, Taylor AE, Clayton RN, Rajkowa M, White D, Franks S, Anttila L, Pettersson KS \& Huhtaniemi IT 1999 A new contributing factor to polycystic ovary syndrome: the genetic variant of luteinizing hormone. Journal of Clinical Endocrinology and Metabolism 84 1711-1715.

Received 21 March 2000

Revised manuscript received 10 August 2000 Accepted 6 September 2000 